\title{
Teaching strategies to foster techno-mathematical literacies in an innovative mathematics course for future engineers
}

\author{
Nathalie J. van der Wal ${ }^{1}\left[\right.$ Arthur Bakker $^{1} \cdot$ Paul Drijvers $^{1}$
}

Accepted: 18 September 2019 / Published online: 26 September 2019

(c) The Author(s) 2019

\begin{abstract}
The workplace practices of engineers have changed due to the ubiquity of digital technology. So-called techno-mathematical literacies $(\mathrm{TmL})$, seen as a domain specification of 21st-century skills, are essential for future engineers. How these TmL can be fostered in their education, however, is still unclear. To address this issue, we conducted a design study in which we developed a course in applied mathematics for higher technical professional education with TmL as central learning goals. This paper describes the design and implementation of the course in a first design cycle with 59 chemistry students. We focus on the teaching strategies that the lecturer used to stimulate the development of students' TmL. In classroom discussions, in the so-called feedback hours on which students' collaborative work on TmL was centered, context-based cases were discussed. Results include didactical, process, and inquiry-based learning strategies used by the lecturer.
\end{abstract}

Keywords Techno-mathematical literacies $\cdot$ Mathematics education $\cdot$ Engineering education $\cdot$ Design research $\cdot$ Inquirybased learning

\section{Introduction}

Technical practices have changed significantly due to the ubiquity of information and communication technology (ICT), digital technology, and computer-driven equipment (Advisory Committee on Mathematics Education 2011). Because of these changes, the development of 21 st-century skills is becoming increasingly important for future work life (Voogt and Roblin 2012). Science, technology, engineering, and mathematics (STEM) education plays an essential role in supporting the development of these skills, integrated with other competencies and content knowledge (Schleicher 2012). Implementing and assessing 21st-century skills is known to be challenging (Ananiadou and Claro 2009); in particular, there is a need to specify and promote these in STEM domains.

Electronic supplementary material The online version of this article (https://doi.org/10.1007/s11858-019-01095-z) contains supplementary material, which is available to authorized users.

Nathalie J. van der Wal

n.j.vanderwal@uu.nl

1 Freudenthal Institute, Faculty of Science, Utrecht University, PO Box 85.170, 3508 AD Utrecht, The Netherlands
As specification of 21st-century skills for the domain of mathematics, the term techno-mathematical literacies $(\mathrm{TmL})$ was introduced by Kent et al. (2005). Bakker et al. (2006) defined TmL as functional mathematical knowledge mediated by tools and grounded in the context of specific work situations (p. 343). They consist of mathematical, workplace and software knowledge, multi-step calculation and estimation (Hoyles et al. 2002), and the ability to interpret abstract data and communicative skills (Hoyles et al. 2013).

Mathematics is often hidden in the interface of the software and is regularly experienced as a black box, so, numerical or graphical output can be unexpected or ill-understood (Kent et al. 2007; Williams and Wake 2007). TmL are rarely learned on the job and need to be developed explicitly (Hoyles et al. 2007). Therefore, they should be considered important learning goals in engineering education.

Ridgway (2000) researched the mathematical needs of engineering apprentices and concluded that mathematics in their work differs in important aspects from mathematics education, and stated that mathematics curricula should support the development of a broad range of skills, practised in contexts. Bakker (2014) investigated the implications of technology for what students need to know about statistics; is the required knowledge more, less or different? His answer is all three: because technology does the computations for 
the user, less knowledge about the exact formulas (e.g., standard deviation-SD) may be needed, but more advanced techniques are faced in workplaces. Moreover, knowledge of technology is needed to do the relevant statistics (e.g., knowing which of the different SD options in Excel should be used in a particular case).

$\mathrm{TmL}$ are intertwined with abstract mathematical knowledge and skills: communication about numerical or graphical data, for example, cannot exist without mathematical expertise in these data. Therefore, when TmL are central learning goals, what does this mean for mathematical content and pedagogy? Table 1 shows which TmL engineers with a background in higher professional education use in their technical practices (Van der Wal et al. 2017). In spite of their importance, $\mathrm{TmL}$ are not explicitly addressed as learning goals in higher technical professional education in the Netherlands. Mathematics education, in particular, is still mainly theoretical with little workplace-related contexts. We notice a gradual introduction of software in these courses, but it is important that $\mathrm{TmL}$ also be introduced. How these $\mathrm{TmL}$ can be supported in mathematics education within technical higher professional education, however, remains unknown.

To address this gap, we conducted a design study to investigate how emphasis on technology use and communication about authentic cases, along with teaching basic mathematics, can promote students' TmL. Our longer-term goal is to design a sustainable course within the prerequisites of the program, which can be taught by multiple lecturers to hundreds of students (Roesken-Winter et al. 2015). For this goal, we need proofs of principle, means of scaling-up, and an evaluation of the course's effectiveness. In previous research on TmL, the focus was merely on tools and tasks (e.g., Bakker and Akkerman 2014; Hoyles et al. 2010). What strategies teachers use in their classes to foster the development of TmL in students, however, was yet to be investigated. Because we needed this information for our largescale implementation of the new course, we analysed what teaching strategies the lecturer used to stimulate TmL reasoning in discussing context-based cases in the first design cycle (Bakker 2018) of an innovative mathematics course for first-year students in life sciences. The research question of the first cycle was as follows: During the discussions of context-based cases, what teaching strategies did the lecturer use to foster TmL?

\section{Background}

In a rapidly changing world, influenced by informatisation, automatisation, digitalisation, and globalisation, knowledge is changing and expanding at high speed. Information sharing, teamwork, and innovation are key, and manual and routine work have become less important because computers and machines accomplish those tasks. New standards of what students should be able to do, instead of basic knowledge and skills of the past, are identified as 21 st-century skills. These include critical and creative thinking, flexible problem solving, ICT literacy, and collaboration and communication skills (Binkley et al. 2012). Development of 21 st-century skills will require systematic instruction and additional resources, over and above what is common in current practice (National Research Council 2013).

Because mathematics is at the core of what computers do, its role increases together with technology. Within STEM education, mathematics appears to be a particularly good fit for the purpose of supporting 21st-century skills, and therefore, its content and pedagogy need to change (Gravemeijer et al. 2017). TmL-categories can be linked to general 21 stcentury skills. Data literacy, sense of error and number are considered specifications of critical thinking. Creative use of software skills and technical drawing skills, and technical communication, reflect essential skills for communication with supervisors, customers, colleagues, etc.

In this study, we focus on engineering education. Therefore, in preliminary research, we administered an interview protocol $(\mathrm{N}=14)$ on the use of $\mathrm{TmL}$ by engineers in their daily practice. We identified seven $\mathrm{TmL}$ categories, listed in Table 1 (van der Wal et al. 2017).

Table 1 The seven TmL categories that engineers use in their work

\begin{tabular}{|c|c|c|}
\hline & TmL category & Description \\
\hline 1 & Data literacy & $\begin{array}{l}\text { The engineer is able to analyse and interpret technical data and graphical representations, draw conclu- } \\
\text { sions and take action accordingly }\end{array}$ \\
\hline 2 & Software skills & The engineer is able to use professional software, e.g., Excel ${ }^{\mathrm{TM}}$ as calculation tools \\
\hline 3 & Technical communication skills & $\begin{array}{l}\text { The engineer is able to communicate technical information with colleagues, customers, supervisors and } \\
\text { other parties }\end{array}$ \\
\hline 4 & Sense of error & The engineer is able to check and verify data and detect errors \\
\hline 5 & Sense of number & The engineer is able to handle and interpret numbers sensibly \\
\hline 6 & Technical creativity & $\begin{array}{l}\text { The engineer is able to produce creative solutions to puzzles and problems (by using, e.g., cleverness or } \\
\text { experience) }\end{array}$ \\
\hline 7 & Technical drawings skills & The engineer is able to understand and produce technical drawings (by using, e.g., spatial insight) \\
\hline
\end{tabular}


To foster the development of TmL, we chose to use an inquiry-based learning (IBL) approach. Inquiry, the use of open questions, is playing an important and growing role in science education, as science is a question-driven process. In this way, inquiry learning mimics as closely as possible the actual pattern of inquiry in science practice. Inquiry in authentic activities motivates students to acquire, understand, and apply science concepts (Linn et al. 1996; Edelson et al. 1999). As the National Research Council (1996) stated: "Scientific inquiry refers to the diverse ways in which scientists study the natural world and propose explanations based on the evidence derived from their work" (p. 23). In this way, inquiry learning reflects the nature of science inquiry.

Chu and colleagues (2017) defined IBL as follows: "A learner-centered approach focussing on questioning, critical thinking and problem-solving. The learner is actively involved in formulating the question/naming a problem" ( $p$. 7). It is a learning process in which students are engaged to stimulate an inquiry mindset and develop understanding and skills (Anderson 2002), supported by the teaching strategy of using process-focussed questions. According to the NSES (1996), inquiry refers to a learning process in which students are engaged. It is said to be an active learning process"something that students do, not something that is done to them" (p. 2).

The idea of inquiry is not new (Barrow 2006). Dewey (1910), a former science teacher, advocated the need for active science practice in science learning rather than the passive reception of knowledge. In this model, there is a central role for the student and for the teacher as a facilitator and guide. Current support for inquiry-based learning comes from cognitive science, which emphasises the importance of authentic contexts for learning (Collins et al. 1992).

Many studies of pre-college instruction have shown improved student learning as a result of inquiry approaches (Savelsbergh et al. 2016). At college-level, findings are mixed on whether inquiry can significantly change student learning or attitudes toward science (Gormally et al. 2009). The American Association for the Advancement of Science (1993), however, stated that inquiry-based teaching methods provide students the opportunity to discuss science and are the best path to scientific literacy. For the designed course in our study, IBL methods were used in the classroom discussions to stimulate creativity, communication, and deep understanding of problem- and context-based learning.

\section{Design rationale}

In the design study described here, we used the methodological orientation of design-based research (Hoadley 2005; Bakker 2018) or educational design research (Plomp 2013), which evolved to bridge the gap between research and practice. It involves developing both theoretical insights and practical solutions in the real world for complex educational problems. The process consists of flexible, iterative cycles of problem analysis and design of the intervention, conducting the intervention, and reflection to produce design principles and adjustment of the design (Cobb et al. 2003). The design process is based on theory and practical experiences, and typically requires teamwork (McKenney and Reeves 2012).

\subsection{Background of the study}

In higher technical professional education in the Netherlands, there are ongoing discussions regarding mathematics education. There is variation both in the expectations of employers and in topics and level of curricula (Van Asselt and Boudri 2013). What all courses have in common, however, is that they are mainly theoretical with very few contexts and workplace-related examples. Classes are taught mainly based on a transmission model, which means transmission of knowledge from an external source to the learners (Vermunt and Verloop 1999). This is the situation also at Avans University of Applied Sciences, where the study took place. This kind of teaching has come under pressure, because it is assumed to lead to inert knowledge, meaning that students may not be able to use this knowledge to solve problems in practice (Brown et al. 1989). It may also have a strong negative association with students' mathematics dispositions (Pampaka and Williams 2016).

At the School for Life Sciences and Technology, part of Avans University of Applied Sciences, the introductory mathematics course previously also consisted of abstract mathematics without context, followed by a written test. A few years previously, pilot studies had been conducted with word problems in the mathematics course. However, students experienced difficulties with recognising and interpreting the mathematics in the text, performance remained low, and the initiative was terminated. After returning to abstract mathematics, the lecturers experienced continuing low student motivation and performance. Furthermore, students did not understand why they have to learn mathematics, and, in the experience of the lecturers, they often did not recognise the mathematics when it was used or needed in other courses.

We suspected that mathematics anxiety played a large role in this phenomenon. In general, roughly $20 \%$ of students appear to suffer from high mathematics anxiety (Ashcraft and Ridley 2005), which is defined as "a feeling of tension and anxiety that interferes with the manipulation of numbers and the solving of mathematical problems in a wide variety of ordinary life and academic situations" (Richardson and Suinn 1972, p. 551). Although chemistry students are expected to suffer less mathematics anxiety on average, this appeared not to be the case in the observation of the 
lecturers. Therefore, a significant change in the introductory mathematics course was imperative.

\subsection{Design team}

The course intervention was designed by the researcher, in collaboration with an interdisciplinary design team of three lecturers from the School for Life Sciences and Technology, the School of Built Environment and Infrastructure (both part of Avans University of Applied Sciences), and the Institute for Engineering and Design (HU University of Applied Sciences Utrecht). These lecturers helped in creating support for innovations, contributed expertise from different technical domains, and provided the technical contexts. The design team met every 3 weeks over approximately 8 months. The tasks of the members consisted of attending the meetings, reading given literature, providing input for the design, developing cases in their specific technical domains, and reviewing each other's cases. We elaborate on these cases in the next section of this paper.

\subsection{Design premises}

The design of the course was based on several premises, provided by the input from the literature, the interview study at engineers' workplaces (van der Wal et al. 2017), and the professional experience of the team members. The learning goals were based on the TmL categories of the interview study and the engineers' opinions and ideas regarding their previous mathematics education. They all experienced it as an island with limited relevance and claimed that it would have been better if mathematics had been taught in context with professional tasks, and related to the other subjects of their major. Furthermore, they assumed this change would make students both more motivated and better prepared for the workplace, where mathematics is always encountered and used in context. This is in line with the results of several studies. Herrington (2006) claimed that more studentcentered, problem-based, and technology-enriched higher education learning environments can engage students, and may enhance learning and retention.

The course should contain a firm base of pure, abstract mathematics of sufficient level because TmL and mathematical knowledge go hand in hand. We implemented a slow progression in mathematical difficulty and the production of calculation tools. Because the course is designed as an introductory mathematics course for every technical domain, such as electrical engineering, computer science, and chemical engineering, the course should cover pre-calculus, with optional adjustments for specific needs in different domains (see Appendix 1 for the mathematical topics).

In some of these domains, the curriculum consisted of just one mathematics course, and it was, therefore, necessary to ensure the course would be sufficient for these students' mathematical needs. In close dialogue with those involved, we chose to add a basis of calculus with a focus on qualitative understanding, rather than computational rules and calculations. For other technical domains, this new course with basic mathematics and qualitative understanding of derivatives and integration was assumed to provide a basis for subsequent courses in calculus.

A research technique often used in design studies is the development of a hypothetical learning trajectory (HLT). Simon (1995) first defined HLT as being comprised of the goal for student learning, the mathematical tasks that will be used to promote student learning, and hypotheses about the process of student learning. The hypotheses and the tasks are interdependent; tasks are chosen based on the hypotheses and vice versa. With this instrument, predictions can be empirically tested, so an effective learning strategy can be developed (Clements and Sarama 2004). In later work, Simon added a framework for thinking about the learning process, the selection of mathematical tasks, and the role of these tasks in the learning process (Simon and Tzur 2004).

The HLT that the design team developed, described the aforementioned premises, the starting situation with the prerequisite mathematical knowledge of the students, the learning goals, the conjectures about students' learning, teaching instructions, the structure of the course, general practicalities and the rationale of the mathematical and pedagogical choices, all of which we elaborate in the following sections of this paper. Because of the uncertain nature of the hypotheses, the HLT could be adjusted at any given moment. Parts of the HLT are presented as examples in Appendix 2.

\subsection{Course structure}

The new course included two parallel learning tracks. In the first track, students practised pre-calculus topics in ALEKS $^{\mathrm{TM}}$, an electronic learning environment, to build a strong mathematical base for the TmL of the second track. For each technical domain, the lecturer has the option to add specific topics, for instance, trigonometry. Students can work individually with this software, outside the classroom, but can ask questions during class hours. Because mathematical self-concept and self-efficacy have been found to have a negative association with mathematics anxiety (e.g., Meece et al. 1990; Pajares and Miller 1994), we assumed that this system could contribute to reducing mathematics anxiety, for students can work at their own level and their own pace, creating experiences of success.

A screenshot of a representative exercise in ALEKS ${ }^{\mathrm{TM}}$ of the first objective (first and second week) is presented in Fig. 1. The ability to use the quadratic formula is necessary for the first case of the second learning track, in which the proton concentration of weak acids is modelled. 
Problem

Explanation

Applying the quadratic formula: Exact answers

QUESTION

Use the quadratic formula to solve for $x$.

$$
4 x^{2}+9 x+3=0
$$

Fig. 1 Screenshot of a representative exercise in ALEKS ${ }^{\mathrm{TM}}$ regarding topics of the first and second week of the course

Table 2 Weekly class hours

\begin{tabular}{ll}
\hline 1st hour & Introduction/questions with lecturer \\
2nd hour & Collaborative work without lecturer \\
3rd hour & Collaborative work without lecturer \\
4th hour & Feedback hour with lecturer \\
\hline
\end{tabular}

The second track, aiming for TmL, consists of working on complex, guided cases in groups of two or three students during class hours, on roughly the same pre-calculus topics as in the ALEKS TM track. Students can work on each case for 2 weeks ( 6 weeks in total) and the seventh and final week is dedicated to completion. The first track focusses on individual learning and the second on collaborative learning. There is no prescribed textbook, because, in our experience, students merely use books for exercises and rarely read the textual explanations. Therefore, we decided that the short texts in the cases would suffice. For each case, a rubric is available for the students and the lecturers (see Appendix 3 for an example). In the method section, we discuss and elaborate upon the design of these cases.

The study load for the course equals two ECTS (European Credit Transfer and Accumulation System), one for each educational track, which is equal to two tracks of $28 \mathrm{~h}$ each. To pass the course, students have to master $90 \%$ of the topics of the ALEKS ${ }^{\text {TM }}$ track. Additionally, they submit their documents for all cases. The summative grade follows from calculating the average grade of the three rubrics, where in each rubric, 0,1 or 2 points can be scored for every question, and the sum is divided by the total score to get the grade. If students fail the review of the cases, they have to pass an oral exam. As for pedagogical choices, we decided to take an inquiry-based, rather than the aforementioned transmission approach. With collaborative learning and classroom discussions, we administered student-centered activities (Teo et al. 2008), which are increasingly used in education in general (Howard et al. 2000).

The course is built on weekly 4-h classes for 7 weeks in total. Table 2 depicts the class structure. In every first hour, the case of that particular fortnight is presented by the lecturer, with a short mathematical instruction added. In every second and third hour, students work on the case in their group, without the lecturer being present. In every fourth hour, the feedback hour, three groups of three students present their work and are queried by the lecturer who is seated among the students in the classroom. Helping each other is the motto of this hour, and creating an open atmosphere is imperative for students to feel safe while presenting, thereby reducing mathematics anxiety.

For complex skills, such as TmL, classroom discussions can stimulate understanding and competence. In these feedback hours, the focus is on assessment for learning, which should have priority over assessment of learning according to Schuwirth and Van der Vleuten (2011). The feedback hours also have the function of testing progress, which has a positive influence on student behaviour by discouraging binge learning (learning in a limited period of time, usually just before the test) and enhances future competence and retention of knowledge (Schuwirth and Van der Vleuten 2012). The choice to assign three clusters of topics in socalled objectives of 2 weeks each in the educational track of ALEKS ${ }^{\text {TM }}$ has the same goal.

As mentioned before, we focussed on inquiry-based learning in the tasks of the cases and in the feedback hours to foster and develop inquiring minds and to help students discover knowledge for themselves. The feedback (how I did it), feed up (where am I going), and feed forward (what is the next step), we used in the feedback hours were assumed to be more effective on the level of process and self-regulation than on the level of tasks (Hattie and Timperley 2007). Therefore, students were asked how they approached the problems, rather than what their answer was. The IBL question strategies that were used in the feedback hours can be found in Appendix 4 (Doorman et al. 2016).

The students in the classroom were expected to contribute actively to the presentations given by their peers. Firstly, presenting groups were asked to show what went well, in order to stimulate an experience of success before addressing the problems they were experiencing. During every feedback (fourth) hour, students were asked to fill in a 'feedback form'. This form is assumed to stimulate student awareness of feedback and activation of its use. In this form, students can elaborate on the feedback they received and how they processed it, as well as the feedback given to other groups, and how they could use that for themselves. Finally, students could describe the contribution to the case by each team member. The feedback form was submitted, along with the cases.

In this course, we chose case-review as the form of assessment, because this form has several advantages. We expect students to get engaged in the feedback hours to improve their documents and to learn from each other, 
whereas written tests can cause too much focus on learning for the test, and also cause much stress for students with a fear of failing. Another important goal of the classroom discussions in the feedback hours is to bridge the two educational tracks of the course, the abstract track of ALEKS ${ }^{\mathrm{TM}}$, which is needed to be able to work on the cases, and developing $\mathrm{TmL}$ and the applied mathematics of the cases. Where students use $x$ and $y$ in ALEKS ${ }^{\mathrm{TM}}$, they use different symbols in the cases, but on the same mathematical topics. In the HLT, specific suggestions are made for lecturers on how and where they can support this bridging.

\subsection{The cases}

The guided cases consist of short pieces of text, pictures, and questions, and are focussed on TmL. Although it is difficult to pinpoint specific behaviours relevant to $\mathrm{TmL}$, especially regarding Tml technical creativity, the design team tried to create questions that address specific aspects of TmL. TmL software skills are practised in all cases using Excel ${ }^{\mathrm{TM}}$ to build calculation tools. TmL data literacy takes up a central position in the cases because of questions focused on analysing, interpreting, and searching data. TmL technical communication skills are practised in exercises in which students are asked to explain and elaborate, and during the classroom discussions in the feedback hours (as explained later in this section). As for the TmL of sense of numbers, we expanded the definition of this TmL category (Van der Wal et al. 2017) to number sense, thus including symbols and formulas. The TmL sense of error and sense of number are addressed by questions of trial and error, interpreting numbers, symbols and formulas, searching for errors, and estimation. TmL technical creativity plays a role in questions in which students are asked to create a solution strategy. The last aspect of TmL, technical drawing skills are not used in the cases of the first cycle because this TmL category is not common in the domain of Chemistry.

The titles of the two cases that the design team developed for the School of Life Sciences are Solutions and acids, and Bacterial growth. The third case, Change, was provided by the School of Built Environment and was adjusted for the domain of life sciences. The cases have several links to other courses in the curriculum. In the section on solutions in the first case, the mathematical topics are linear functions and equations, and in the section on acids, quadratic functions and equations are addressed. This case starts with a worked example because for novice learners it is more effective to add an example before the problem-solving phase (Van Gog et al. 2011). The second case discusses bacterial growth by means of exponential, logarithmic, and rational functions and equations. The last case addresses the subject of change through a qualitative approach to calculus. In the first part of this case, distance, time, and speed of a runner are chosen, because this context stimulates an intuitive understanding of change. In the last part, the design team added a chemical topic. All cases consist of short pieces of text with pictures and contain 15-40 questions, and the third case also uses apps in Geogebra ${ }^{\mathrm{TM}}$.

In the cases, students are stimulated to develop TmL with other types of tasks that go beyond mere calculations. For example, TmL sense of error was practised in the last question of the first case on solutions and weak acids. In this section, the concentration of the protons $\left(\mathrm{H}^{+}\right)$in weak acids is modelled as a function of the acid concentration $m$. The variables $K_{a}$, the acid constant, and $r$, the added proton concentration, are fixed in cells B1 and B3. Students are asked to find the error in one of the two solutions of the quadratic formula in linear form for the calculation of the proton concentration. In Appendix 5, the Excel ${ }^{\mathrm{TM}}$ screenshot is given. Can you find the error?

$=\left(-(\$ B \$ 3+\$ B \$ 1)+S Q R T\left((\$ B \$ 3+\$ B \$ 1)^{2}-A 7 * \$ B \$ 1\right)\right) / 2$

In the electronical supplementary material, the integral version of this case is given, with the answers, the rationale on TmL, and parts of the HLT.

\section{Method}

\subsection{Participants}

The implementation of the first cycle with 59 first-year students (26 female, 33 male) of the Chemistry major, aged 17-21 years old, divided over three groups, was conducted by the researcher and a member of the design team from the School for Life Sciences and Technology. The new course was named Applied Mathematics and implemented in the curriculum of the Chemistry major in the second half of the second semester. Because of the different learning goals, a control group would not have yielded a fair comparison.

\subsection{Data collection}

Data collection concerning the teaching strategies consisted of video-recordings of all feedback hours, with their TmLfocussed class discussions. These meetings were filmed every week for the two classes that were taught by the researcher, resulting in 12 lessons of 45 min of video. The camera with a built-in microphone was set up in the middle of the classroom, facing the digital board and the presenting students in the front. Because the lecturer was ill in the fifth week, there were no classes that week, and therefore the video data consist of 12 instead of 14 lessons. The students of these two classes were asked to sign consent forms for using this material for research purposes; we used the data of those 30 students, out of a total of 35 , who signed for approval. 


\subsection{Data analysis}

Data analysis was performed using a version of the constant comparative method (CCM). Watching all video recording chronologically, and, with the HLT and research question as theoretical orientations, initial conjectures were generated, and when necessary were revised during further analysis of subsequent episodes (cf. Cobb and Whitenack 1996). In this way, teaching strategies of the lecturer relevant to conducting feedback hours and to stimulating $\mathrm{TmL}$ learning were identified in the first two recorded feedback hours and tested in the successive feedback hours. The analysis led to a list with occurrences of teaching strategies used during every student presentation (each lasting approximately $15 \mathrm{~min}$ ). These occurrences are meant as a descriptive overview of teaching strategies used, and not as a generalisation.

In each second and third hour of the 4-hour schedule (see Table 2), the students worked collaboratively on the cases. Often, they did not finish the assigned work in the given time. During the feedback hours, when students presented their work, the lecturer continuously promoted discussion by using particular IBL strategies, until some intended TmL reasoning among the group was observed and most students expressed understanding (as judged during teaching). Hence, we concluded that the intended $\mathrm{TmL}$ reasoning was realised.

In the analysis, we distinguished pedagogical and process strategies that we considered conditional for conducting each feedback hour, from specific IBL strategies that stimulated elicitation of TmL. In this paper, we focus on the latter. We investigated and listed how the lecturer used IBL questions in the classroom interactions, and looked for moments in which the lecturer used certain teaching strategies, such as asking students to elaborate on what they did, or how they solved certain problems (technical communication skills), to find an error (sense of error), leading discussions on the several expressions of a formula (sense of numbers and technical creativity) or discussing the interpretation of data (data literacy). In case 2 , for example, an expression of an equation had to be transformed (sense of numbers). After discussing how the students handled this problem and listing the several answers students had given, the lecturer encouraged the class to formulate a general approach to these kinds of problems.

Another member of the design team, who was not involved in teaching the course, was provided with the list of teaching strategies that the researcher had identified and asked to analyse independently $1.5 \mathrm{~h}$ of the video data, to compare findings and to test agreement on interpretation (peer examination). He identified several teaching strategies from the provided list, but also some others. Most of these other strategies appeared to be similar to the ones already identified but were formulated differently or were considered part of another strategy. For example, we agreed that "asking a student how a particular calculation changes with different numbers" (as formulated by the second coder) could be seen as a part of the strategy of "asking deeper questions about data, tables, formulas, and figures" as formulated by the first coder. Two identified teaching strategies were explicitly new and were added to the list.

\section{Results}

\subsection{Pedagogical and process strategies}

The pedagogical and process strategies that were frequently used by the lecturer are provided in the first two rows of Table 3 with the occurrences in brackets. Firstly, we saw the deliberate use of expectation and process management, because the structure and way of assessment of the course were more complex than, and different from, most other courses of the curriculum. Every week, the lecturer set out the program of the feedback hour, chose groups of students to present, and often reminded the students to open the feedback form on their laptops, and she repeated how to use it. Secondly, she often elaborated on the learning goals of the course. For instance, she mentioned that being able to explain your work (TmL technical communication) is an important skill for future work life, which requires ample practice.

Furthermore, we saw a constant effort to achieve a good and safe atmosphere in the class, including using positive phrasing, emphasising the aim of helping one another, stimulating applause for one another, and using humour. Students started their presentation of their work with a part that went well to stimulate a success experience. Later on, they were asked where they got stuck so that the whole class could help. Finally, the students chose group names, and we had the impression that their choices, which were often playful, added positivity to the atmosphere in the classroom. We heard, for example, The Algebro's, SyntaxError, and The MathCrew, but also nonmathematical names.

\subsection{IBL strategies}

Relating to fostering the development of $\mathrm{TmL}$, we saw a variety of IBL strategies used, both general and TmLspecific. When students presented their work, the lecturer constantly structured the process with comments and recapitulated the explanations and answers of the students. Then further questions were asked to deepen the thought processes, and classroom discussions on the topic were encouraged. For example, students were asked to spot an error, to formulate a general approach to a certain problem, or to elaborate on the general subject of the case. 
Table 3 Teaching strategies used by the lecturer during the feedback hours, with numbers of occurrences in brackets

Pedagogical strategies

Encourages applauding for each other (16); formulates in a positive way and uses humour (8); acknowledges the difficulty of the subject (7); encourages pride for their work in students (5); stimulates that this hour is meant for helping one another (2); encourages feedback from students on the cases to further improve them for future students (2); addresses possible feelings of frustration in students (2)

Process strategies

Stimulates the students to write down feedback of others that they can use themselves (5); explains the rationale of the assignment (4); checks the progress of the groups and adjusts accordingly (3); stimulates students to write down the feedback after presentation (3); asks the contribution of each student to the product (2); asks what students need to continue before ending the class (2); encourages students to let their thoughts simmer on the problem after class (2); encourages more collaborative working and emphasises not to divide sections between group members (1)

General IBL strategies

Structures answers and theory and recapitulates what students say (27); asks how students will proceed with this problem (13); gives a tip (12); starts problem-solving on whiteboard and asks students to finish (11); asks where students got stuck (9); explains connection between math and other courses or future professions (9); compares heuristics used in groups (7); asks students to show something that went well (stimulating success experience) (6); asks what the thought process was (1); discusses the way one can work on these cases, advantages and disadvantages of strategies (1)

TmL specific IBL strategies

For all TmL: asks deeper questions about data, tables, formulas, and figures (35)

For TmL technical communication: encourages taking a helicopter view in elaborating (23); asks a student to elaborate on the answer (9); asks class to formulate a general strategy (4). encourages explaining to one another (3); encourages rephrasing in own words (1)

For TmL Sense of number and sense of error: asks class to spot an error (7); stimulates to use numbers that are realistic or easy (4); lets students discover their mistake by stimulating thinking about the logical answer (2)

For TmL technical software skills: asks a student to show and explain their Excel ${ }^{\mathrm{TM}}$ calculation tool live (5)

\subsection{Challenges}

The lecturer also faced some challenges. In classroom activities, it proved not always possible to engage every student. In the videos, we saw a few students who were distracted by their phones or were yawning and almost sleeping. In late classes, students could be tired, or perhaps some experienced the assignment as too simple. A few students complained about the difficult phrasing of some questions. The lecturer then asked how they would formulate them. The students often concluded that they had not read the questions properly. Furthermore, after working in their groups in the $2 \mathrm{~h}$ without the lecturer, not every group had finished the same amount of work. The lecturer had to consider these differences and choose presenting groups carefully.

\subsection{Classroom dialogues}

To illustrate findings, we present two examples of classroom dialogues and discussions, in which the lecturer used IBL strategies to support the learning of TmL. In the first week, TmL technical communication skills were practised in the feedback hour with the whole class in the first case. This TmL category was continuously stimulated in every feedback hour, but in the excerpt below, we focus explicitly on how to explain something. Students often struggled with this skill; they tended to start with details and often could not see the whole picture. The lecturer (L) tried to practise how explaining something could be structured with the presenting students (PD) and the other students in the classroom (S), to generate a template for this aspect.
L Can you explain what the example at the start of this case is about?

PS1 Uh...we fill in variables in the equation

L That's right. But let's take some steps back. If you look at the worked example, which we started with, which we build upon this whole case, what was it about?

PS1 Uh...it is about the $\mathrm{H}^{+}$concentration where you add a certain volume

L Yes, that is a part of it, indeed. OK, the goal of this is to learn to explain things, what you do. That can be difficult, and that is why we practise it. Student 2 [in class], can you try to explain the example?

S2 There is a solution with a $\mathrm{pH}$ of 1.5 , and by adjusting the formula and by adding variables, you can calculate other concentrations

L That is what we do after the example, indeed, but let's look at the example again, what do we start with?

S3 [in class]. You start with $20 \mathrm{~mL}$ of $1 \mathrm{~mol}$ per litre $\mathrm{HCl}$, then we add a certain volume of $0.25 \mathrm{~mol}$ per litre $\mathrm{HCl}$, so you get a solution....with $\mathrm{pH} 1.5$

L Indeed. So, what is important when you have to explain such a thing, is that you start with what you have, and then explain where you want to go

In the next example from the feedback hour of the third lesson, regarding the case about bacterial growth, the lecturer tried to focus on the TmL of sense of error, software skills, and some technical creativity by asking specific IBL questions. First, she asked students to show the formula in Excel ${ }^{\mathrm{TM}}$, to stimulate the students in developing software skills: 
L How did you implement a generation time of 0.5?

PS4 We used the same formula but made another timetable, $0,0.5,1 \ldots$ etc.

$\mathrm{L} \quad$ Can you show the formula?

The lecturer now focussed on the formula and asked questions about what to expect for the number of bacteria, to give the students the opportunity to discover that something was wrong (sense of error).

L Ok, suppose we start with one bacterium, can you change that? [S4 adjusts the cell in Excel ${ }^{\mathrm{TM}}$ with the aid of other students (technical software skills)]. So, when we start with one bacterium and the generation time is $1 \mathrm{~h}$, how many bacteria do you have after $1 \mathrm{~h}$ ? PS5 2

$\mathrm{L} \quad 2$, indeed. And when the generation time is 0.5 , how many bacteria do you have after $1 \mathrm{~h}$ ?

PS5 4

The students saw that they did not have this amount. Then the lecturer tried to stimulate technical creativity by asking for another solution to this problem. She mentioned that the students used a timetable from $0,1,2 \ldots$ and changed that into $0,0.5,1,1.5,2.5 \ldots$, and acknowledged that this solution was a smart way to adjust the generation time, but then asked whether there might be an alternative way. If the timetable was kept as in the beginning, how could the formula be adjusted? The lecturer helped the students by suggesting the solution was in the adjustment of the formula. She could have chosen not to disclose this point, to challenge the students even more. A student in the class then replied with "dividing by a half". Subsequently, the lecturer practised sense of error, by asking whether one has to divide by half or multiply by a half to obtain four bacteria after an hour.

\section{Conclusion and discussion}

In this study, we addressed the question of what teaching strategies the lecturer used to foster techno-mathematical literacies in an innovative mathematics course. Through collaboration within an interdisciplinary STEM design team, we designed an innovative mathematics course with a central role for TmL. Firstly, TmL learning is stimulated by using context-based cases, adjusted to specific technical domains. The guiding questions in the cases are designed to stimulate TmL by not only focussing on producing calculations but also, for example, detecting errors (TmL sense of error), elaborating (TmL technical communication) and stimulating creating alternative solutions ( $\mathrm{TmL}$ technical creativity).

The feedback hours, with their classroom discussions, and usage of IBL questions, seem to contribute to the learning of TmL. The lecturer used a variety of teaching strategies for this purpose, including prerequisite strategies such as process management. IBL strategies are used to enhance learning in general, but also to specifically address TmL. Conducting the feedback hours appears to ask a lot from the lecturer, who has to take multiple roles, as a teacher, coach, discussion leader, and organiser.

The results of this first cycle function as a proof of principle, and the premises of the course, described in this paper, are an example of how the development of $\mathrm{TmL}$ can, in principle, be fostered. By choosing TmL as learning goals in mathematics education, the development of these skills is made explicit (Hoyles et al. 2007). In combining those learning goals with IBL teaching strategies in context-rich materials, we hope to contribute to well-prepared students who can transfer and apply knowledge to solve problems in their working future (Brown et al. 1989; Voogt and Roblin 2012; Ridgway 2000).

In this paper, we did not address the collaborative work of the students in the hours without the lecturer present, nor did we report on the revision of the course after the first cycle. Because the administering of this course with its process and expectation management, and IBL approach, is demanding for the lecturer, we recommend training to prepare lecturers for this sort of TmL focussed mathematics education. We also would like to create more open instead of guided cases, to stimulate increased development of TmL. With all the changes students and lecturers already face with this innovation, however, we will postpone this next step to a later stage.

For the second cycle, a large implementation for all majors of the School of Life Science has been administered, and because of the complex character of all the challenges involved, we decided to add a study on how lecturers can be effectively supported, in which we would build on very different literature, namely on teacher professional development. The second and third cycles are, therefore, the topic of a future report. A fourth design cycle will be devoted to measuring the effectiveness of the course by means of pre- and posttests. We hope that the design, premises, and implementation of this new course will be an example and inspiration of how mathematics education can contribute to the development of 21st-century skills.

Acknowledgements This work is part of the research programme Doctoral Grant for Teachers, with project number 023.009.061, which is financed by the Netherlands Organisation for Scientific Research (NWO). We would like to thank Albert Moes, Wilfred Kleinjan and Hans Vrijmoeth for their excellent work in the design team, and Thijs van Bruchem for providing the third case about change.

Open Access This article is distributed under the terms of the Creative Commons Attribution 4.0 International License (http://creativeco mmons.org/licenses/by/4.0/), which permits unrestricted use, distribution, and reproduction in any medium, provided you give appropriate credit to the original author(s) and the source, provide a link to the Creative Commons license, and indicate if changes were made. 


\section{Appendix 1}

Mathematical topics in the applied mathematics course

1. Linear functions, equations, and graphs.

2. Solving systems of linear equations

3. Quadratic functions, equations, and graphs.

4. Rational functions, equations, graphs, and computational rules.

5. Exponential functions, equations, graphs, and computational rules.

6. (Natural) logarithmic functions, equations, graphs, and computational rules.

7. Qualitative approach to derivatives and integration.

8. Optional: trigonometry, vectors, and matrices.

\section{Appendix 2}

Parts of the HLT with teaching instructions and TmL in case-questions.

\section{TmL as learning goals}

The applied mathematics course has a focus on mathematics in workplace contexts and a central role in fostering TmL. The TmL we use in this course are data literacy, software skills, technical communication skills, sense of number, sense of error, and technical creativity. In the cases, students use Excel ${ }^{\mathrm{TM}}$ to develop a calculation tool, as part of TmL software skills.

\section{A teaching instruction for the feedback hour}

In the feedback hour, two groups are invited to present their case. Firstly, ask the groups to present a part that went well and of which they are proud, to create an experience of success. Then continue to the part where students encounter difficulties. Try to help the students and activate the rest of the class by using inquiry-based questions which focus on the process, rather than the answers. What do you know here? What is the next step? How did you approach this? Is there another way to solve this? Explain your method to the class, etc. In the IBL form [Appendix 4] you can find more process related questions you can use.

\section{Instructions for bridging abstract and applied mathematics}

[In question 13 of the second case, students are asked to derive one formula from another with calculation rules]

During the feedback hour, after the formula is derived, ask the presenting group what kind of function this is (linear), what the main formula is of such a function $(y=a x+b)$, and which variable represents $x, y, a$, and $b$, to support recognition of abstract mathematics in applied formulas.

\section{Appendix 3}

Part of the rubric of the first case

\begin{tabular}{|c|c|c|c|}
\hline Question & 2 points & 1 point & 0 points \\
\hline 1 & $\begin{array}{l}\text { Correct formula } \\
\text { incorrect lay- } \\
\text { out and Excel } \\
\text { formula, table and } \\
\text { graph (including } \\
\text { titles) correct }\end{array}$ & $\begin{array}{l}\text { Formula correct } \\
\text { OR Excel } \\
\text { correct }\end{array}$ & Both incorrect \\
\hline 3 & $\begin{array}{l}\text { Equation formed and } \\
\text { solved correctly } \\
\text { with unity, and } \\
\text { graph correct }\end{array}$ & Partly incorrect & Incorrect \\
\hline 7 & $\begin{array}{l}\text { Calculation posed } \\
\text { and solved correctly } \\
\text { and indicated which } \\
\text { solution for } \mathrm{x} \text { is } \\
\text { right. }\end{array}$ & Partly incorrect & Both incorrect \\
\hline 8 & $\begin{array}{l}\text { Function/formula } \\
\text { correctly posed and } \\
\text { simplified }\end{array}$ & Partly incorrect & Both incorrect \\
\hline 9 & $\begin{array}{l}\text { Tables, graphs } \\
\text { (including titles) } \\
\text { and trend lines } \\
\text { correct }\end{array}$ & Partly incorrect & Incorrect \\
\hline 13 & $\begin{array}{l}\text { Equilibrium equation } \\
\text { and answer to the } \\
\text { negative a correct }\end{array}$ & $\begin{array}{l}\text { One of two cor- } \\
\text { rect }\end{array}$ & Both incorrect \\
\hline 14 & $\begin{array}{l}\text { Derive to quadratic } \\
\text { equation and solv- } \\
\text { ing correctly }\end{array}$ & $\begin{array}{l}\text { One of two cor- } \\
\text { rect }\end{array}$ & Both incorrect \\
\hline 15 & Debugging correct & & $\begin{array}{r}\text { Debugging } \\
\text { incorrect }\end{array}$ \\
\hline
\end{tabular}

\section{Appendix 4}

IBL questions for the feedback hour, Doorman et al. 2016, p. 42

\begin{tabular}{|c|c|}
\hline IBL teaching strategies & Suggested questions \\
\hline $\begin{array}{l}\text { Allow students time to under- } \\
\text { stand the problem and engage } \\
\text { with it }\end{array}$ & $\begin{array}{l}\text { Take your time, don't rush } \\
\text { What do you know? } \\
\text { What are you trying to do? }\end{array}$ \\
\hline $\begin{array}{l}\text { Discourage students from rush- } \\
\text { ing in too quickly or from } \\
\text { asking you to help too soon }\end{array}$ & $\begin{array}{l}\text { What is fixed? What can be } \\
\text { changed? } \\
\text { Don't ask for help too quickly- } \\
\text { try to think it out between you. }\end{array}$ \\
\hline
\end{tabular}


IBL teaching strategies

Suggested questions

Offer strategic rather than technical hints

Avoid simplifying problems for students by breaking it down into steps

Encourage students to consider alternative methods and approaches

Encourage students to compare their own methods

Encourage explanation

Make students do the reasoning and encourage them to explain to one another
How could you get started on this problem?

What have you tried so far?

Can you try a specific example?

How can you be systematic here?

Can you think of a helpful representation?

Is there another way of doing this?

Describe your method to the rest of the group

Which of these two methods do you prefer and why?

Can you explain your method?

Can you explain that again differently?

Can you put what Sarah just said into your own words?

Can you write that down?

\begin{tabular}{|c|c|}
\hline IBL teaching strategies & Suggested questions \\
\hline $\begin{array}{l}\text { Model thinking and powerful } \\
\text { methods }\end{array}$ & $\begin{array}{l}\text { Now I'm going to try this problem } \\
\text { myself, thinking aloud }\end{array}$ \\
\hline $\begin{array}{l}\text { When students have done all } \\
\text { they can, they will learn from } \\
\text { being shown a powerful, ele- } \\
\text { gant approach. If this is done } \\
\text { at the beginning, however, they } \\
\text { will simply imitate the method } \\
\text { and not appreciate why it was } \\
\text { needed }\end{array}$ & $\begin{array}{l}\text { I might make some mistakes } \\
\text { here-try to spot them for me } \\
\text { This is one way of improving the } \\
\text { solution }\end{array}$ \\
\hline
\end{tabular}

\section{Appendix 5}

The Excel ${ }^{\mathrm{TM}}$ input provided to detect the error in the formula.

\begin{tabular}{|c|c|c|c|c|c|c|c|c|c|c|}
\hline \multicolumn{2}{|c|}{ AANTAL } & \multirow[t]{2}{*}{ 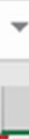 } & \multirow{2}{*}{$\begin{array}{l}\vdots \\
\quad \mathbf{B} \\
\end{array}$} & $\checkmark \quad f_{x}$ & \multicolumn{6}{|c|}{$=\left(-(\$ B \$ 3+\$ B \$ 1)+W O R T E L\left((\$ B \$ 3+\$ B \$ 1)^{\wedge} 2+A 7^{*} \$ B \$ 1\right)\right) / 2$} \\
\hline$\Delta$ & A & & & C & D & $\mathrm{E}$ & $\mathrm{F}$ & G & $\mathrm{H}$ & 1 \\
\hline 1 & $\mathrm{Ka}$ & & $6,30 \mathrm{E}-05$ & & & & & & & \\
\hline \multicolumn{11}{|c|}{2} \\
\hline 3 & $r$ & & 0,010 & & & & & & & \\
\hline \multicolumn{11}{|c|}{4} \\
\hline 5 & $\mathrm{~m}$ & {$\left[\mathrm{H}^{-}\right.$} & $\left.{ }^{+}\right]_{1}$ & {$\left[\mathrm{H}^{+}\right]_{2}$} & $\mathrm{pH}$ & & & & & \\
\hline \multicolumn{11}{|l|}{6} \\
\hline 7 & 0,00 & & $(\$ B \$ 3+\$ B$ & $-1,01 E-02$ & & & & & & \\
\hline 8 & 0,02 & & $3,12 \mathrm{E}-05$ & $-1,01 E-02$ & 4,51 & & & & & \\
\hline 9 & 0,04 & & $6,22 \mathrm{E}-05$ & $-1,01 E-02$ & 4,21 & & & & & \\
\hline 10 & 0,06 & & $9,30 \mathrm{E}-05$ & $-1,02 \mathrm{E}-02$ & 4,03 & & & & & \\
\hline 11 & 0,08 & & $1,24 \mathrm{E}-04$ & $-1,02 \mathrm{E}-02$ & 3,91 & & & & & \\
\hline 12 & 0,10 & & $1,54 \mathrm{E}-04$ & $-1,02 E-02$ & 3,81 & & & & & \\
\hline 13 & 0,12 & & $1,84 \mathrm{E}-04$ & $-1,02 \mathrm{E}-02$ & 3,73 & & & & & \\
\hline 14 & 0,14 & & $2,15 \mathrm{E}-04$ & $-1,03 E-02$ & 3,67 & & & & & \\
\hline 15 & 0,16 & & $2,44 \mathrm{E}-04$ & $-1,03 E-02$ & 3,61 & & & & & \\
\hline 16 & 0,18 & & $2,74 \mathrm{E}-04$ & $-1,03 E-02$ & 3,56 & & & & & \\
\hline 17 & 0,20 & & $3,04 \mathrm{E}-04$ & $-1,04 E-02$ & 3,52 & & & & & \\
\hline 18 & 0,22 & & $3,33 \mathrm{E}-04$ & $-1,04 \mathrm{E}-02$ & 3,48 & & & & & \\
\hline 19 & 0,24 & & $3,63 \mathrm{E}-04$ & $-1,04 E-02$ & 3,44 & & & & & \\
\hline 20 & 0,26 & & $3,92 \mathrm{E}-04$ & $-1,05 E-02$ & 3,41 & & & & & \\
\hline 21 & 0,28 & & $4,21 \mathrm{E}-04$ & $-1,05 E-02$ & 3,38 & & & & & \\
\hline 22 & 0,30 & & $4,49 \mathrm{E}-04$ & $-1,05 \mathrm{E}-02$ & 3,35 & & & & & \\
\hline
\end{tabular}




\section{References}

Advisory Committee on Mathematics Education. (2011). Mathematics in the workplace and in higher education. London: The Royal Society.

Ananiadou, K., \& Claro, M. (2009), 21st century skills and competences for new millennium learners in OECD countries, OECD Education working papers, no. 41, OECD Publishing. https://doi. org/10.1787/218525261154.

Anderson, R. D. (2002). Reforming science teaching: What research says about inquiry. Journal of Science Teacher Education, 13(1), $1-12$.

Ashcraft, M. H., \& Ridley, K. S. (2005). Math anxiety and its cognitive consequences. In J. I. D. Campbell (Ed.), Handbook of mathematical cognition (pp. 315-327). New York: Psychology Press.

Bakker, A. (2014). Implications of technology on what students need to know about statistics. In T. Wassong, D. Frischemeier, P. R. Fischer, R. Hochmuth, \& P. Bender (Eds.), Mit Werkzeugen Mathematik und Stochastik lernen-Using Tools for Learning Mathematics and Statistics (pp. 143-152). Wiesbaden: Springer Spektrum.

Bakker, A. (2018). Design research in education: A practical guide for early career researchers. London: Routledge.

Bakker, A., \& Akkerman, S. F. (2014). A boundary-crossing approach to support students' integration of statistical and work-related knowledge. Educational Studies in Mathematics, 86(2), 223-237.

Bakker, A., Hoyles, C., Kent, P., \& Noss, R. (2006). Improving work processes by making the invisible visible. Journal of Education and Work, 19(4), 343-361.

Barrow, L. H. (2006). A brief history of inquiry: From Dewey to standards. Journal of Science Teacher Education, 17(3), 265-278. https ://doi.org/10.1007/s10972-006-9008-5.

Binkley, M., Erstad, O., Herman, J., Raizen, S., Ripley, M., MillerRicci, M., \& Rumble, M. (2012). Defining twenty-first century skills. In P. Griffin, B. McGaw, \& E. Care (Eds.), Assessment and teaching of 21 st century skills (pp. 17-66). Dordrecht: Springer.

Brown, J. S., Collins, A., \& Duguid, P. (1989). Situated cognition and the culture of learning. Educational Researcher, 18(1), 32-42.

Chu, S. K. W., Reynolds, R. B., Tavares, N. J., Notari, M., \& Lee, C. W. Y. (2017). 21st century skills development through inquiry-based learning: From theory to practice. Singapore: Springer.

Clements, D. H., \& Sarama, J. (2004). Learning trajectories in mathematics education. Mathematical Thinking and Learning, 6(2), $81-89$.

Cobb, P., Confrey, J., Lehrer, R., \& Schauble, L. (2003). Design experiments in educational research. Educational Researcher, 32(1), $9-13$.

Cobb, P., \& Whitenack, J. W. (1996). A method for conducting longitudinal analyses of classroom videorecordings and transcripts. Educational Studies in Mathematics, 30(3), 213-228.

Collins, A., Greeno, J., Resnick, L. B., Berliner, B., \& Calfee, R. (1992). Cognition and learning. In B. Berliner \& R. Calfee (Eds.), Handbook of educational psychology (pp. 15-46). New York: Simon \& Shuster MacMillan.

Dewey, J. (1910). Science as subject-matter and as method. Science, $31,121-127$.

Doorman, M., Jonker, V., \& Wijers, M. (2016). Mascil in the classroom. In N. Kuijpers, K. Maass, \& K. Reitz-Koncebovski (Eds.), Mathematics and science in life: Inquiry learning and the world of work (p. 42). Freiburg: University of Education.

Edelson, D. C., Gordin, D. N., \& Pea, R. D. (1999). Addressing the challenges of inquiry-based learning through technology and curriculum design. Journal of the Learning Sciences, 8(3-4), 391-450.
Gormally, C., Brickman, P., Hallar, B., \& Armstrong, N. (2009). Effects of inquiry-based learning on students' science literacy skills and confidence. International Journal for the Scholarship of Teaching and Learning, 3(2), 16.

Gravemeijer, K., Stephan, M., Julie, C., Lin, F. L., \& Ohtani, M. (2017). What mathematics education may prepare students for the society of the future? International Journal of Science and Mathematics Education, 15(1), 105-123.

Hattie, J., \& Timperley, H. (2007). The power of feedback. Review of Educational Research, 77(1), 81-112.

Herrington, J. (2006). Authentic learning environments in higher education. London: Information Science Publishing.

Hoadley, C. M. (2005). Design-based research methods and theory building: A case study of research with "SpeakEasy". Educational Technology, 45(1), 42-47.

Howard, B. C., McGee, S., Schwartz, N., \& Purcell, S. (2000). The experience of constructivism: Transforming teacher epistemology. Journal of Research on Computing in Education, 32(4), 455-465.

Hoyles, C., Noss, R., Kent, P., \& Bakker, A. (2010). Improving mathematics at work: The need for techno-mathematical literacies. London: Routledge.

Hoyles, C., Noss, R., Kent, P., \& Bakker, A. (2013). Mathematics in the workplace: Issues and challenges. In A. Damlamian, J. F. Rodrigues, \& R. Sträßer (Eds.), Educational interfaces between mathematics and industry (pp. 43-50). London: Springer.

Hoyles, C., Noss, R., Kent, P., Bakker, A., \& Bhinder, C. (2007). Techno-mathematical literacies in the workplace: A critical skills gap. London: Teaching and Learning Research Programme (TLRP).

Hoyles, C., Wolf, A., Molyneux-Hodgson, S., \& Kent, P. (2002). Mathematical skills in the workplace. London: Science, Technology and Mathematics Council.

Kent, P., Bakker, A., Hoyles, C., \& Noss, R. (2005). Techno-mathematical literacies in the workplace. Mathematics Statistics and Operational Research, 5(1), 5-9.

Kent, P., Noss, R., Guile, D., Hoyles, C., \& Bakker, A. (2007). Characterizing the use of mathematical knowledge in boundary-crossing situations at work. Mind, Culture, and Activity, 14(1-2), 64-82.

Linn, M. C., Songer, N. B., \& Eylon, B. S. (1996). Shifts and convergences in science learning and instruction. In B. Berliner \& R. Calfee (Eds.), Handbook of educational psychology (pp. 438490). New York: Routledge.

McKenney, S., \& Reeves, T. (2012). Conducting educational design research. London: Routledge.

Meece, J. L., Wigfield, A., \& Eccles, J. S. (1990). Predictors of math anxiety and its influence on young adolescents' course enrollment intentions and performance in mathematics. Journal of Educational Psychology, 82, 60-70. https://doi. org/10.1037/0022-0663.82.1.60.

National Research Council. (1996). National science education standards. Washington, DC: National Academies Press.

National Research Council. (2013). Education for life and work: Developing transferable knowledge and skills in the 21st century. Washington, DC: National Academies Press.

Pajares, F., \& Miller, M. D. (1994). The role of self-efficacy and selfconcept beliefs in mathematical problem-solving: A path analysis. Journal of Educational Psychology, 86, 193-203. https://doi. org/10.1037/0022-0663.86.2.193.

Pampaka, M., \& Williams, J. (2016). Mathematics teachers' and students' perceptions of transmissionist teaching and its association with students' dispositions. Teaching Mathematics and its Applications: An International Journal of the IMA, 35(3), 118-130.

Plomp, T. (2013). Educational design research: An introduction. In T. Plomp \& N. Nieveen (Eds.), An introduction to educational design research (pp. 10-51). Enschede: SLO. 
Richardson, F. C., \& Suinn, R. M. (1972). The mathematics anxiety rating scale: Psychometric data. Journal of Counseling Psychology, 19, 551-554.

Ridgway, J. (2000). The mathematical needs of engineering apprentices. In A. Bessot \& J. Ridgway (Eds.), Education for mathematics in the workplace (pp. 189-197). Dordrecht: Kluwer Academic Publishers.

Roesken-Winter, B., Hoyles, C., \& Blömeke, S. (2015). Evidencebased CPD: Scaling up sustainable interventions. ZDM Mathematics Education, 47(1), 1-12.

Savelsbergh, E. R., Prins, G. T., Rietbergen, C., Fechner, S., Vaessen, B. E., Draijer, J. M., et al. (2016). Effects of innovative science and mathematics teaching on student attitudes and achievement: A meta-analytic study. Educational Research Review, 19, 158-172.

Schleicher, A. (2012). Preparing teachers and developing school leaders for the 21st century: Lessons from around the world. Paris: OECD Publishing.

Schuwirth, L. W., \& Van der Vleuten, C. P. (2011). Programmatic assessment: From assessment of learning to assessment for learning. Medical Teacher, 33(6), 478-485.

Schuwirth, L. W., \& van der Vleuten, C. P. (2012). The use of progress testing. Perspectives on Medical Education, 1(1), 24-30.

Simon, M. (1995). Reconstructing mathematics pedagogy from a constructivist perspective. Journal for Research in Mathematics Education, 26, 114-145.

Simon, M. A., \& Tzur, R. (2004). Explicating the role of mathematical tasks in conceptual learning: An elaboration of the hypothetical learning trajectory. Mathematical Thinking and Learning, 6(2), 91-104.
Teo, T., Chai, C. S., Hung, D., \& Lee, C. B. (2008). Beliefs about teaching and uses of technology among pre-service teachers. AsiaPacific Journal of Teacher Education, 36(2), 163-174.

Van Asselt, R., \& Boudri, J. C. (2013). Versterking van de doorstroom en de kwaliteit van het technisch $\mathrm{HBO}$; Adviezen vanuit het onderwijswerkveld [Reinforcing flow and quality of higher technical professional education; Advice from educational practices]. Nieuwekerk aan de IJssel: Landelijke Werkgroep HBO Wiskunde.

Van der Wal, N. J., Bakker, A., \& Drijvers, P. (2017). Which Technomathematical Literacies are essential for future engineers? International Journal of Science and Mathematics Education, 15(Supplement 1), 87-104.

Van Gog, T., Kester, L., \& Paas, F. (2011). Effects of worked examples, example-problem, and problem-example pairs on novices' learning. Contemporary Educational Psychology, 36, 212-218.

Vermunt, J. D., \& Verloop, N. (1999). Congruence and friction between learning and teaching. Learning and Instruction, 9(3), 257-280.

Voogt, J., \& Roblin, N. P. (2012). A comparative analysis of international frameworks for 21 st-century competences: Implications for national curriculum policies. Journal of Curriculum Studies, 44(3), 299-321.

Williams, J., \& Wake, G. (2007). Metaphors and models in translation between college and workplace mathematics. Educational Studies in Mathematics, 64, 345-371.

Publisher's Note Springer Nature remains neutral with regard to jurisdictional claims in published maps and institutional affiliations. 